\title{
EFL Learning Motivation: Lifelong Enjoyment
}

\author{
Yuichi Todaka ${ }^{1, *}$ \\ ${ }^{1}$ Miyazaki Municipal University, Japan \\ *Correspondence: Miyazaki Municipal University, Japan. E-mail: todaka@miyazaki-mu.ac.jp \\ Received: March 3, $2020 \quad$ Accepted: June 2, 2020 Online Published: July 15, 2020 \\ doi:10.5430/ijelt.v7n2p24 URL: https://doi.org/10.5430/ijelt.v7n2p24
}

\begin{abstract}
This study is part of a five-year consecutive study designed to help college freshmen change their view of English learning as a tedious activity to one where they see it as a lifelong enriching experience. In the first two studies we focused on self-efficacy sources. In the third study we added focus on the development of future EFL selves with image training. We then shifted our attention toward the establishment of concrete and fun English study reasons that are associated with students' hobbies and interests using YouTube videos as authentic learning support material outside the classroom. In these studies we were able to help our students improve their English listening skills during the spring semester, but those students were unable to maintain that proficiency level over the summer breaks or during the subsequent fall semester. Thus, in this present study, we added explicit instruction on how to access and make use of certain YouTube sites in order to improve English listening skills. Based on our findings, this most recent method helped our freshmen significantly improve their English skills, even during the spring semester and summer break, and for the most part improve their English listening skills during the fall semester as well.
\end{abstract}

Keywords: motivation, fun reasons, lifelong learning, authentic material

\section{Introduction}

Todaka (2019) reports that research on ESL/EFL students' English language learning has continued to proliferate as motivation is recognized as a crucial requisite for successful second language learning (Dörnyei, 2001, 2005; Dörnyei \& Schmidt, 2001; Lamb 2017; Boo et al., 2015). However, researchers have not agreed upon what roles different components of motivation such as individual differences, and cultural factors play. Nonetheless, many recent intervention activities can be categorized into the following ideas:

\subsection{Self-efficacy}

Ever since Bandura (1977) proposed self-efficacy theory, many articles in various fields such as psychology, sociology, kinesiology, and medicine have been published. Bandura (1977) outlined the four sources of self-efficacy: (1) performance outcomes; (2) vicarious experiences; (3) verbal persuasion; and (4) physiological feedback. Performance outcomes denote that our positive or negative experiences can influence our ability to perform a given task. Vicarious experiences are thought of as the influence of someone else's success or failure on one's high or low self-efficacy. Verbal persuasion means that our self-efficacy is affected by what others say to us about what they believe we can do or not. Finally, physiological feedback is described as comfortable physiological and emotional sensations that are likely to lead one to have high self-efficacy in a given situation.

According to Todaka (2013), Raoofi et al (2013: 63-65) reviewed 32 articles published between 2003 and 2012 with regard to the effectiveness of self-efficacy theory in the ESL/EFL contexts. Among the 32 articles reviewed, 12 articles examined the relationship between self-efficacy beliefs and ESL/EFL performance based on either course grades (Mahyuddin et al., 2006; Mills, Pajares, \& Herron, 2007; Hsieh \& Schallert, 2008) reading proficiency (Mills, Pajares \& Herron, 2006; Mills, Pajares, \& herron, 2007), or listening (Mills, Pajares, \& Herron, 2006; Magogwe \& Oliver, 2007; Tilfarlioglu \& Cifici, 2011). The findings of these studies indicate a positive relationship between self-efficacy and performance. This is in line with findings in other research domains such as math, and education in general (Dennissen et al., 2007; Multon et al., 1991; Pajares, 1996). Furthermore, 7 articles examined the relationship between self-efficacy and anxiety (Mills, Pajares \& Herron, 2006; Erkan \& Saban, 2011; Anyadubalu, 2010; Cubukcu, 2008) 
and between self-efficacy and attributions (Hsieh \& Kang, 2010; Hsieh \& Schallert, 2008; Graham, 2006). The findings of these studies indicate a significant negative relationship between one's self-efficacy level and ESL/EFL performance. Students with high self-efficacy attribute their failure to a lack of effort, whereas students with low self-efficacy attribute their failure to their own low ability.

\subsection{L2 Motivational Self System (Dörnyei, 2005, 2009) with Magery Training}

This system stresses the importance of L2 learners' self-perceptions of their desired future self-states. The intensity of that motivation partly depends on learners' ability to produce mental imagery (Dörnyei and Chan, 2013). Markus and Nurius (1987: 159 cited in Dörnyei and Chan, 2013: 440) report that "possible selves encompass within their scope visions of desired and undesired end states." Dörnyei and Chan (2013) assert that L2 learners with a vivid ideal self-image are more likely to motivate themselves to carry out the necessary tasks to realize their desired 'future selves' that are associated with English skills. In other words, if L2 learners can visualize their future as one in which they can utilize their English skills in their careers, they tend to motivate themselves to study English and to sustain that motivation as they continue to study.

Imagery training involves a specific set of dimensions (e.g. vividness, controllability, duration, the difficulty in evoking an image, the ease of formation of an image, perspective taken) and modalities (e.g. visual, kinesthetic, auditory, tactic, gustatory and olfactory (Chan, 2014: 56). Research indicates that imagery abilities can be improved through training, which implies that rhater than being seen as abilities, they would be better characterized as skills that make full use of the six senses. (i.e., visual, kinesthetic, auditory, tactile, gustatory, and olfactory (Morris et al., 2005 cited in Chan, 2014: 56).

\subsection{Efficacy of Mobile Language Learning on L2 Learning}

Use of mobile phones as a pedagogical support tool has become very attractive and widespread (Cho et al. 2018: 2). Cho et al. (2018:2) describe the reasons why teachers and students have come to rely on mobile technologies: (1) Mobile phones are nearly always present in daily life; (2) Smartphones can be used as hand-held computers to support learning activities with integrated technologies such as voice recorder/player; and (3) Numerous mobile applications are being developed for educational activities.

Ozer \& Kilic (2018) report that mobile learning technologies can assist EFL teachers in vocabulary teaching (Chen \& Li, 2010; Kim \& Kim, 2012), and grammar teaching (Hsu, Hwang, \& Chang, 2013). In addition, mobile language technologies can help EFL learners improve writing skills (Ivic \& Jakopec, 2016), and pronunciation/communication skills (Hwang, Huang, Shadiev, Wu, \& Chen, 2014). Ozer \& Kilic (2018) report that EFL students who learned in a mobile-assisted language learning environment experienced statistically significant improvement in academic achievement.

Viberg and Gronlund (2017: 1) report on advantages of MALL (mobile-assisted language learning): "low cost, small size and user-friendliness, researchers are exploring how to use mobile technology to support language learning (Hauang et al., 2012 cited in Viberg and Gronlund, 2017:1)." Viber and Gronlund (2017: 5) further describe MALL as follows:

'Experiment' (non-strictly defined) is the most commonly applied method in the reviewed studies (47\%), followed by interpretive case studies (28\%). Together these two methods make up 75\% of the research published 2007-2012. Most studies are small-scale, exploratory, and conducted within a short period of time, which makes them rather anecdotal in terms of reliability. This is not surprising given that the field of MALL is in its developmental experimental phase and still needs more solid empirical evidence and guidance in order to underpin conclusions about how mobile technologies can assist language learning acquisition and in order to build theoretical models specific to this field. It is hence still an open question to what extent MALL in the L2 area is indeed different from MALL in other areas.

\subsection{Advancements in Information and Communication Technology}

Balbay \& Selcan (2017:235) report that "one of the most remarkable tools used in teaching and learning in the $21^{\text {st }}$ century is YouTube, especially in language education." The use of YouTube in education can be an excellent tool to teaching ESL/EFL students (Duffy, 2008; Roodt \& Villiers, 2011; and Roodt \& Peier, 2013 cited in Zaidi et al., 2018). Since thousands of video clips on various topics and in many languages can be found on YouTube, speaking, listening and conversation activities utilizing YouTube have been conducted (e.g. Watkins and Eilkins, 2011; Snelson, 2009 cited in Zaidi et al., 2018: 544).

Benmouhoub (2014: 29), however, describes the disadvantages of any technical tool, such as YouTube as follows: (1) time constraints; (2) limited software; (3) passive viewing; and (4) fear of technology. This is where blended learning 
comes in.

Prihastiwi et al. (2017: 2) describe blended learning as "a mixture of online and traditional face-to-face planned class activities." Larson (2010) cited in Bandivilai (2016: 224) found that "students were found to work more autonomously and to be focused while becoming more responsible for their own learning." In addition, Bandivilai (2016) reported that blended learning improved all of the four language skills of Thai EFL students as well as their ability for autonomous learning and learner motivation.

In addition, as mentioned earlier, authentic materials such as YouTube can help students understand the real world outside. Cheung (2001:60 cited in Kelson, 2009) states that "popular culture is a rich source of authentic materials, bridging the gap between formal and informal English learning, and developing learning based on students' daily experience, personal values, attitudes and feelings." YouTube hosts videos that are now viewed more than 2 billion times each day ("Timeline," 2011 cited in Watkins and Watkins, 2011:113). Watkins and Watkins (2011: 114) describe the effectiveness of YouTube on English learning as follows:

First, students can, in their own time, choose to view a YouTube clip in English, evaluate possible limitations of comprehension on their own terms, and finally choose (or choose not) to pursue further academic attention for that particular area. Secondly, after exposure to a YouTube clip, a fairly advanced and linguistically self-aware student can determine approximately which pronunciation and conversation skills are desired and then attempt to acquire them. Thirdly, a student can browse the millions of videos available on YouTube without needing help from any teacher or fellow student. Fourthly, if a student finds a particular kind of clip (or YouTube channel) particularly interesting or useful in language learning, he or she can freely investigate all clips that might be of a similar vein. Finally, if a student feels the material being studied in class is not useful, then an intelligent and self-guided examination into YouTube could be conducted to supplement what the student feels is being overlooked or suppressed by the educational institution.

\subsection{Establishment of Self-customized Concrete and Fun English Study Reasons}

Todaka (2017b) reports on the importance of establishing new and concrete English study reasons to help Japanese college freshmen sustain their motivation to study English. He speculates that the establishment of concrete and fun English study reasons can be a crucial prerequisite for intervention activities that focus on imagery to help Japanese college freshmen set short-term/long-term goals and sustain motivation to study English.

A goal is a desired result that an EFL learner would like to achieve. But to achieve a goal it is important for EFL learners to truly understand why she/he wants to study English in the first place. Agawa et al. (2011, p. 13, cited in Sampson, 2016, p. 16) uncovered amotivation in a university setting, when the participants in their demotivation study participants noted 'no interest in foreign languages, cultures or people' and 'not understanding for what purpose English is being studied' in their study responses (my translation, Sampson, 2016:16).

Sampson (2016, p. 17) supports this finding with the following:

The literature suggests perceived relevance of English study to be an integral influence on the motivation of Japanese students. Sitting in classrooms week in week out as part of a set of compulsory subjects, many learners may have only a vague idea of the purpose of their EFL studies and be uncertain as to how they might use English in the future.

Indeed, most Japanese high school students study English only to pass college entrance exams. Todaka (2013) therefore reports on the importance of the establishment of concrete English study reasons for college students. As described above, previous studies have found the effectiveness of intervention activities with an emphasis on self-efficacy, imagery and of mobile-assisted L2 learning environment on the improvement of various EFL skills. However, Todaka $(2017 b, 2018,2019)$ states that EFL learners, especially de-motivated learners, do not have English study reasons to begin with. Self-determination theory (Deci \& Ryan, 2000) focuses on how students can motivate themselves rather than how teachers can motivate students. Noels and colleagues (2000, 2001 cited in Keblawi, 2020) showed that students' motivation is enhanced when teachers allow for more learner autonomy (p. 34). Vohs et al. (2008 cited in Keblawi, 2020) did however find that allowing students too many choices may lead to negative effects on self-regulation (p. 35). Keblawi (2020) for example, warns against giving full attention on the goal of mastering L2, though the importance of goals in sustaining L2 motivation has been attested by goal theories by stating, "...concentration only on future goals, particularly the long-term goal of mastering the language, might distract teachers' attention from the fact that learners' intrinsic enjoyment and innate curiosity are both vital sources of motivation."

Todaka (2019: 4-5) reported that there is the necessity for ESL learners to create a future self with specific goals in 
order to improve their English skills. We also agree that mobile L2 learning can be a useful tool for de-motivated Japanese college EFL learners during their EFL learning stages. However, we also find that it is imperative for de-motivated Japanese college EFL learners to understand why they need/want to study English in college in class. Our university, for example, is a small municipal institution in which most of our students go on to graduate and work for companies where no English skills are required. Many therefore continue on through college with no more consideration for why they should study English than they had before college. For this reason, it is important to help our students understand that there are other reasons for the study of English, be it for the purpose of finding a more fulfilling career in the future, or for simply the pursuit of a personal hobby, and that they have the right to decide for themselves their own reasons for their English study and their own potential future uses of English in their lives.

Thus, Todaka (ibid) reports that given that learning enjoyment and curiosity are important sources of motivation, it is important for teachers to create the conditions where individual learners can associate their hobbies and interests with their English study. The use of mobile phones as an in class pedagogical technique won't work for those students who are more interested in using conventional devises such as CD or DVD players. Kelson (2009) used YouTube as a supplementary material in the classroom, and found that some of the students responded as "I don't know how to use it" and "I don't know what to find." Therefore, students, who are more interested in using conventional devices, such as $\mathrm{CD}$ and DVD players, can enjoy improving English listening skills by listening to English songs and/or watching favorites movies.

In our first three studies students' English listening skills improved during the spring semester, but deteriorated during the summer break. In our 2018 academic year study however, for the first time during the four years of our study, students' English listening skills did not deteriorate during the summer break. Thus, by providing students with information on various YouTube sites in connection with the establishment of concrete and fun English study reasons, freshmen in the 2018 study were able to continue to sustain their motivation even during the summer break. It is, however, important to note that, as Kelson (ibid) reported, some of students last year mentioned that they couldn't make use of the sites on YouTube because they didn't know how to use it. Thus, in this 2019 academic year study, we taught students how to get access to various sites on YouTube, and we showed them some of the sites our freshmen were interested in in the present study.

The objectives of the present study are two-fold: (1) to provide de-motivated Japanese college freshmen with information on various sites on YouTube so that sites relating to their hobbies and interests can be utilized to improve their English listening skills. During class, we will also explicitly show the students how to use YouTube effectively; and (2) to help students self-customize their personal interest-based English study reasons to suit their needs based on (a) the YouTube site information, (b) English study reasons that motivated Japanese EFL learners' possess, (c) on possible jobs they can hold with EFL skills, and (d) about what their classmates' English study reasons, hobbies, and future dreams are in class. The last three pieces of information described here were found to be very useful by students in our 2017b study. We also decided to actually show our learners some of the sites on YouTube to further assist in establishing their own intrinsic (or extrinsic) tailor-made English study reasons in face-to-face class activities. Motivation studies need a 'person-in-context approach' (Ushioda, 2009: 23). Therefore, during the initial learning stages, we decided to allow learners the ability to establish extrinsic English study reasons if those individual learners wanted to study English because of extrinsic rewards.

\section{Hypothesis}

If de-motivated Japanese college freshmen can be made to understand that their concrete English study reasons can used be for their own benefit (not just passing English classes, but for self-improvement), and that those same concrete study reasons can also be associated with simple hobbies such as listening to English music, watching English movies, or putting on make-up, then providing those students with useful hobby-related information from English YouTube sites, individual learners can come to understand that they can receive abundant authentic English input while continuing to enjoy their pastime doing what they like on their smartphones and computers, if indeed students prefer using smartphones and computers over conventional CD and DVD players. Thus, by creating the conditions (i.e. modified blended learning) in which individual learners can self-customize their English study reasons, students can sustain their motivation to improve their English listening skills. We provided students with ample information on various sites on YouTube so that students who would like to study English using cell phones can do so. Of course, those students who prefer to use more conventional devises to study English, such as CD or DVD players for example, could still utilize those conventional devises to enjoy learning English.

The hypothesis was formulated based on the premise that all the YouTube sites we introduced are English language 
sites. Learners who are interested in learning how to put on make-up, for example, can learn to do so by watching a video clip spoken in English (English subtitles can be seen). Because an actual person is demonstrating how to put on the make-up in the video, the visual cues that accompany the demonstration can help learners understand what the person is actually saying. In addition, those learners are more likely to make use of the English subtitles to fully understand the demonstration because they are genuinely interested in the topic. Furthermore, providing our de-motivated Japanese college freshmen with various interesting sites on YouTube can help them sustain their motivation to enjoy English even if their motives for L2 learning change from time to time. Our project did not use MALL technologies in class. As stated above, we provided students with ample information on various sites on YouTube so that students who would like to study English using cell phones can do so, while students who prefer to use more conventional devices, such as CD or DVD players to study English can still utilize those conventional devices to enjoy learning English.

\section{Intervention Strategies Conducted in the Present Study}

The following intervention strategies were exactly the same as those used in the previous year's study with the exception that, in this project, we explicitly taught students how they should use YouTube and actually showed them some examples of useful YouTube sites to help them understand what kinds of videos they will have access to.

\section{Lesson 1}

Students were asked to fill out a questionnaire (Appendix 1) to report on their reasons for studying English in high school and college. Students in groups of four then discussed their reasons for English study in high school. The instructor made clear to them that they should also discuss what they liked or disliked about English classes in high school. Group leaders then shared the information of likes and dislikes about English classes in high school to the whole class. This activity was done to help students realize that they need to revise their English study reasons as they move on to college (Activity 1 ).

Two samples of English study reasons gathered from 1419 motivated Japanese EFL learners (sourced from https://ceburyugaku.jp/42159/ and https://www.marshresearch.co.jp/mini_research/mr201402english.html) were distributed to students in groups of four. The students reviewed the summary of reasons why some of those 1419 adult Japanese EFL learners study English and discussed what their own English study reasons could be. The instructor had group leaders report on the possible English study reasons that each group found relevant to themselves. Each of the students was then asked to think carefully about his/her own hobbies and interests until the next class and to write them down on a sheet of paper (Activity 2). Reminders to carefully consider their own English study reasons were then given throughout the spring semester.

\section{Lesson 2}

Students were provided with two sample lists (sourced from eigotextbook.com kaplaninternational.com) that describe the merits of English study skills for the future and the types of future jobs students can hold with EFL skills. Student each read the samples and worked in groups of four to talk about the possible jobs they can hold in the future with English skills. The instructor had group leaders report on the jobs that each group found interesting. The instructor reminded students to consider their own English study reasons when they thought about possible future jobs with English skills (Activity 3).

Each group wrote down their new and concrete English study reasons and possible future careers with EFL skills, and presented them to their classmates. All of the information was collected, to be redistributed in the next lesson. Group activities help students broaden student thinking, help them connect themselves with the information and provide support for thinking about their future selves (Sampson, 2012: 328,).

\section{Lesson 3}

Each student first read the list of new and concrete English study reasons and possible future jobs with EFL skills gathered during the previous lesson as a reference for the establishment of their own concrete English study reasons. Each student then carefully modified his/her own new/concrete English study reasons that were associated with their hobbies and interests, keeping in mind the possible future jobs that can be held with EFL skills. We discussed the importance of establishing fun and interesting new/concrete English study reasons so that students can enjoy themselves as they improve their English listening skills (Activity 4).

\section{Lesson 4}

Students in groups of four shared their own tailor-made English study reasons. The instructor and the classroom 
assistant joined each group to find out what fun and interesting English study reasons students were able to come up with. Group leaders then presented to the whole class the information their groupmates shared (Activity 5). The instructor reminded that studying English doesn't have to be something they don't like. On the contrary, reasons to study English can and should be fun and exciting. Thus, students were reminded to consider their hobbies and interests before they self-customize their English study reasons. Group leaders wrote down the groupmates' hobbies and interests on the board, and the instructor summarized the information. Finally, the instructor told students that YouTube sites that deal with students' interests and hobbies, and information on English-speaking activities with native and non-native English speakers in Miyazaki City will be given from the next class forward.

\section{Lesson 5}

The classroom assistant introduced to the students 12 international events in Miyazaki city to students because some of our students' fun English study reason was to make friends and communicate with native English speakers and improve their English communication skills. The assistant briefly described each of the events and gave the information on the access site on which interested students can be members of the events. The classroom assistant also shared information about English Cafe. English Café is a once-a-week meet-and-greet type gathering of native English speakers (English language assistants from Miyazaki secondary schools) and Japanese people who are interested in speaking English. (Activity 6).

In addition, based on Todaka (2009) and Todaka and Misono (2009), prominent learning constructs/strategies for promoting English listening skills were taught. Specifically these constructs/strategies were (1) background knowledge of various topics, (2) phonetic knowledge of English, (3) working memory capacity: ability to recognize, perceive, and memorize short segments of incoming speech, (4) knowledge of various dialects of English, (5) written materials to assist learners in understanding spontaneous speech, and (6) various tasks to provide learners with ample opportunities to listen to authentic English (Activity 7).

\section{Lesson 6}

Some students indicated that they like to play games during their free time, so the assistant introduced techniques on how to improve students' English communication skills through games. The assistant showed students various enjoyable games they can play with people from different parts of the world so that they can make friends and interact with non-Japanese game players in English (Activity 8). The instructor next taught the prominent differences between Japanese and English sentence stress to help students improve their English listening and pronunciation skills (Activity 9).

\section{Lessons 7}

Many of our female students indicated that they wanted to learn about current fashion and make-up trends. The classroom assistant introduced some sites on YouTube where actresses or people working for fashion brands show how to put on make-up or dress according to recent trends. The assistant told students that they can access these sites on their smart phones whenever they have free time outside of class. Students then studied the major differences in rhythm between Japanese and English.

\section{Lesson 8}

Some students also reported an interest in ethnic cooking so the assistant introduced some sites on YouTube where students can learn about foods from different parts of the world and how to cook foreign foods. Students then studied linking, one of the sound adjustments in English connected speech, in order to improve their English listening and pronunciation skills.

\section{Lesson 9}

Some students were found to be very interested in finding out how their favorite actors/actresses actually speak, so the assistant introduced some sites on YouTube where famous actors/actresses were interviewed on talk shows or at premieres. Students then studied assimilations, one of the sound adjustments in connected speech to improve their English listening and pronunciation skills.

\section{Lesson 10}

The assistant introduced some sites on YouTube on which famous sightseeing spots around the world are introduced by people in English as many of our students were found to be interested in traveling around the world. The assistant told them that they can virtually travel anywhere in the world and enjoy seeing famous sightseeing spots on their smartphones. Students then studied elision, one of the sound adjustments in connected speech, to improve their English listening and pronunciation skills. 


\section{Lesson 11}

The assistant introduced some sites on YouTube where famous festivals in different parts of the world are presented in English, since some students are interested in world festivals. Students then reviewed the three different types of connected speech sound adjustments they studied in previous lessons.

\section{Lesson 12}

Many students indicated that they are interested in English songs singing English songs in Karaoke booths so the classroom assistant introduced some sites on YouTube where student can hear explanations on how to sing English songs well. Students then studied the prominent differences between Japanese and English intonation.

\section{Lesson 13}

The assistant introduced to students how they can improve their English speaking and listening skills utilizing English movies. The instructor then demonstrated how to improve their English communication skills using shadowing techniques with English movies. A one-minute scene from the movie 'Matrix' was selected and the instructor presented step-by-step shadowing techniques (e.g. Teeter, 2017) so that those students who are interested in English movies can watch them and improve their English communication skills at the same time. Students then studied the prominent differences between Japanese and English intonation.

\section{Lesson 14}

Some students reported that they are interested in improving their English pronunciation, so the assistant introduced some sites on YouTube that explain and demonstrate how to improve English pronunciation. Students then reviewed the major differences between Japanese and English word stress, sentence stress, and rhythm.

\section{Lesson 15}

Students were asked to fill out a questionnaire about their English study reasons and motivation to improve their English listening skills (appendix 2). They were also asked if the YouTube sites introduced in the class helped them enjoy improving their English listening skills. The instructor then reviewed the English sound adjustments and intonation techniques that were studied in previous classes. Finally, students in groups of four discussed the importance of concrete English study reasons that are associated with their hobbies and interests, and each of the group leaders presented to the whole class what his/her group had discussed.

\section{Methodology}

\subsection{Participants}

148 Miyazaki Municipal University freshmen students/participated in this study.(Note 1) They were categorized into four groups according to their university English program placement test scores: (1) 37 students were grouped as introductory level students; (2) 71 students were placed in two intermediate classes (37 students in intermediate I class and 31 students in intermediate II class) and; (3) 40 students were assigned to an advanced class. Regardless of the study grouping however all of the participants should be considered as low introductory to low intermediate level students, as their mean TOEIC listening test scores ranged from 315.9 to 326.5 among nine TOEIC tests that was officially conducted in Japan in 2017.

The study participants attended both CALL and language acquisition classes throughout the entire academic year, in 15 weekly classes over the spring and fall semesters. They attended the CALL classes in the groupings described above and the language acquisition classes as one entire freshman group seated in a large lecture hall.

\subsection{Additional Instruction Aside from Intervention Strategy Activities}

The CALL classes were taught by the author in the following way: (1) lectures on important English suprasegmental features (e.g., Vance 1987; Todaka 1995); (2) various exercises specifically designed to teach phonetic features; (3) advice on various listening strategies for the needs of individual students; and (4) evaluation of progress according to self-assessment checklist items. In this study, we also focused on the following to provide students with a comfortable learning environment in the spring semester:

(a) Positive role models:

One teaching assistant, a senior at the same university, participated in all classes and functioned as a role model for the study participants.

(b) Relaxed classroom environment: 
The instructor carefully provided a classroom environment in which students could feel free to ask questions and where students were not afraid of making mistakes.

(c) Verbal support:

The instructor always reminded students that anyone can improve his/her English listening skills if he/she understands and employs appropriate learning strategies.

(d) Appropriate and interesting class materials:

Materials were specifically designed and adjusted to students' proficiency levels so that students could retain confidence in their English listening skills throughout the term. In addition, the instructor made sure to utilize instructional procedures that ensure students understand step-by-step strategies to improve their English listening skills.

(e) Team work:

Classroom activities were mainly carried out in pairs or in small groups so that students could assist one another in understanding effective ways to improve their English listening skills. Members of pairs or groups were changed weekly so that students had opportunities to work with many different classmates.

(f) Regular assessment:

Weekly quizzes were given. All of the question items on each quiz were taught in advance. The objective of the weekly quizzes was to make sure students incrementally understood the important strategies for improving their English listening skills.

(g) Reminders of the importance of concrete English study reasons that are associated with students' hobbies and interests:

Throughout the school year, the teacher presented constant of the importance of the above points, during the CALL classes. During the fall semester however, the author did not teach the CALL classes, so these reminders were provided at the beginning of the lecture in the author's language acquisition class.

\subsection{Assessment Tools}

Students' English listening skill improvement was evaluated using the results of TOEIC. The listening portions of two different TOEICs were administered at the beginning and end of the spring and fall semesters in the 2019 academic year. In addition, we formulated a ten-item self-efficacy questionnaire to further assess our students' English listening skills. Because self-efficacy perceptions are both context- and task-specific (Maddux 2002) and cultural context-specific (Oettingen, 1995), we specifically designed this self-efficacy questionnaire to assess our students' level of motivation during the spring, summer, and fall semesters of the 2019 academic year (see Appendix 2).

\section{Results and Discussion}

The following table shows the percentage of students in each proficiency group who understand why they need to study English in college. The data were collected during the first class session in April, 2018 in comparison with the April 2019 data.

Table 1. The Number of Students Who Understand Why They Need to Study English in College

\begin{tabular}{ccc}
\hline Months/Groups & April 2018 & April 2019 \\
\hline Introductory & $0 \%$ & $0.9 \%$ \\
Intermediate I & $5 \%$ & $21 \%$ \\
Intermediate II & $23 \%$ & $20 \%$ \\
Advanced & $16 \%$ & $38 \%$ \\
\hline
\end{tabular}

As can be seen, most freshmen in the 2018 and the 2019 studies do not understand why they need to study English in college. This trend can be seen among students in all the proficiency groups. In addition, as expected, the lower the English proficiency level, the fewer the number of students that understand why they need to study English even in college.

Some students do indeed understand the importance of English skills in the future. However, as Todaka (2018) reports, 
an understanding of the importance of EFL skills for future benefit alone cannot help all of our students take the necessary actions to carry out English study in their daily lives. The understanding of the importance of EFL skills cannot be the only motive to study English because many students don't have any concrete and fun English study reasons to begin with. In other words, while some students reported that they want to study abroad during college, this type of English study reason is not specific enough for students to carry out the necessary tasks in their daily lives to improve their English skills.

On the other hand, most students studied English in secondary school simply because they had to do so., It is interesting to note however that while some students did indicate that they liked English or that they understand the importance of English skills in the future, they still do not understand why they need to study English in college. In fact, some students stated specifically that they like to listen to English songs or watch English movies; they assumed however that English classes in college would also focus on vocabulary and grammatical structures. Thus, they might have felt no interest for English study in college, because they sensed that they would be forced to study only the linguistic aspects of English they are not interested in.

The following table shows the percentage of students in each proficiency group who were able to sustain their motivation to improve their English listening skills during the last four years. The data were collected three different times: (1) July; (2) October; and (3) January.

Table 2. The Number of Students Who Sustained Their Motivation to Improve English Listening Skills (2016, 2017, 2018, and 2019 studies)

\begin{tabular}{ccccccccccccc}
\hline Year & \multicolumn{3}{c}{ The 2016 academic } & \multicolumn{2}{c}{ The 2017 academic } & \multicolumn{2}{c}{ The 2018 academic } & \multicolumn{2}{c}{ The 2019 academic } \\
& \multicolumn{3}{c}{ year } & & year & & year & & year \\
\hline Months/Groups & July & Oct. & Jan. & July & Oct. & Jan. & July & Oct. & Jan/ & July & Oct. & Jan/ \\
\hline Introductory & $71 \%$ & $12 \%$ & $26 \%$ & $57 \%$ & $24 \%$ & $74 \%$ & $100 \%$ & $73 \%$ & $90 \%$ & $95 \%$ & $63 \%$ & $68 \%$ \\
Intermediate I & $67 \%$ & $10 \%$ & $50 \%$ & $68 \%$ & $29 \%$ & $69 \%$ & $100 \%$ & $64 \%$ & $82 \%$ & $92 \%$ & $86 \%$ & $80 \%$ \\
Intermediate II & $75 \%$ & $6 \%$ & $42 \%$ & $57 \%$ & $33 \%$ & $59 \%$ & $93 \%$ & $74 \%$ & $89 \%$ & $97 \%$ & $95 \%$ & $78 \%$ \\
Advanced & $77 \%$ & $19 \%$ & $67 \%$ & $57 \%$ & $30 \%$ & $59 \%$ & $100 \%$ & $88 \%$ & $90 \%$ & $100 \%$ & $85 \%$ & $86 \%$ \\
\hline
\end{tabular}

Figures1 through 4 indicate the results in the above table graphically. As can be seen from the figures, the number of students who sustained their motivation to study English increased to almost 100\% from April to July in the 2018 and the 2019 studies. In addition, when compared with the 2016 and the 2017 study results, the number of students who were able to sustain their motivation to study English during the summer break increased from $12 \%$ (2016 study) and $24 \%$ (2017 study) to 63\% (2019 study) and 73\% (2018 study) among the introductory students. As for the intermediate I class, the number increased from 10\% (2016 study) and 29\% (2017 study) to 64\% (2018 study) and 86\% (2019 study). With respect to the intermediate II students, the number increased from 6\% (2016 study) and 33\% (2017 study) to 74\% (2018 study) and 95\% (2019 study). Finally, among the advanced students, the number boosted from 19\% (2016 study) and 30\% (2017 study) to $85 \%$ (2019 study) and 88\% (2018 study).

While there was a high percentage of students able to sustain their motivation during the summer break, it seems that the number of students able to continue to sustain that motivation to study English during the fall semester decreased in the intermediate I and II classes in this study. It is, however, important to note that almost $80 \%$ except of the introductory students were able to sustain their motivation to study English during the fall semester. The number of students in the 2018 and the 2019 academic years who were able to sustain their motivation during the summer break, tremendously increased when compared with the students in the 2016 and the 2017 academic years.

Todaka (2017b) reports on the four crucial differences in pedagogy between the 2016 and 2017 academic year studies: (1) in the 2017 study, we provided our students with samples of concrete English study reasons among motivated Japanese students of English, and we utilized those samples to help our students carefully consider the true reasoning behind their own English study throughout the academic year; (2) we provided students with samples of possible jobs they could obtain with EFL skills in the future; (3) students shared information on their responses to various intervention activities so that they were better able to understand what their classmates had thought about their concrete English study reasons, possible EFL selves, visualization techniques, and so forth; and (4) we incorporated various intervention activities with an emphasis on imagery.

The crucial differences between the 2017 and 2018 academic year studies, on the other hand, were as follows: (1) we 
provided students with various YouTube sites that focused on their hobbies and interests in order to help them self-customize their concrete/fun English study reasons, and (2) we excluded various intervention activities with an emphasis on imagery. The only difference between the 2018 and the 2019 academic-year studies was that, in this study, because some students in the 2018 study indicated that they had difficulty accessing and using various sites on YouTube by themselves, we explicitly taught them in class, how to use those various sites on YouTube, rather than merely providing students with the information on YouTube.

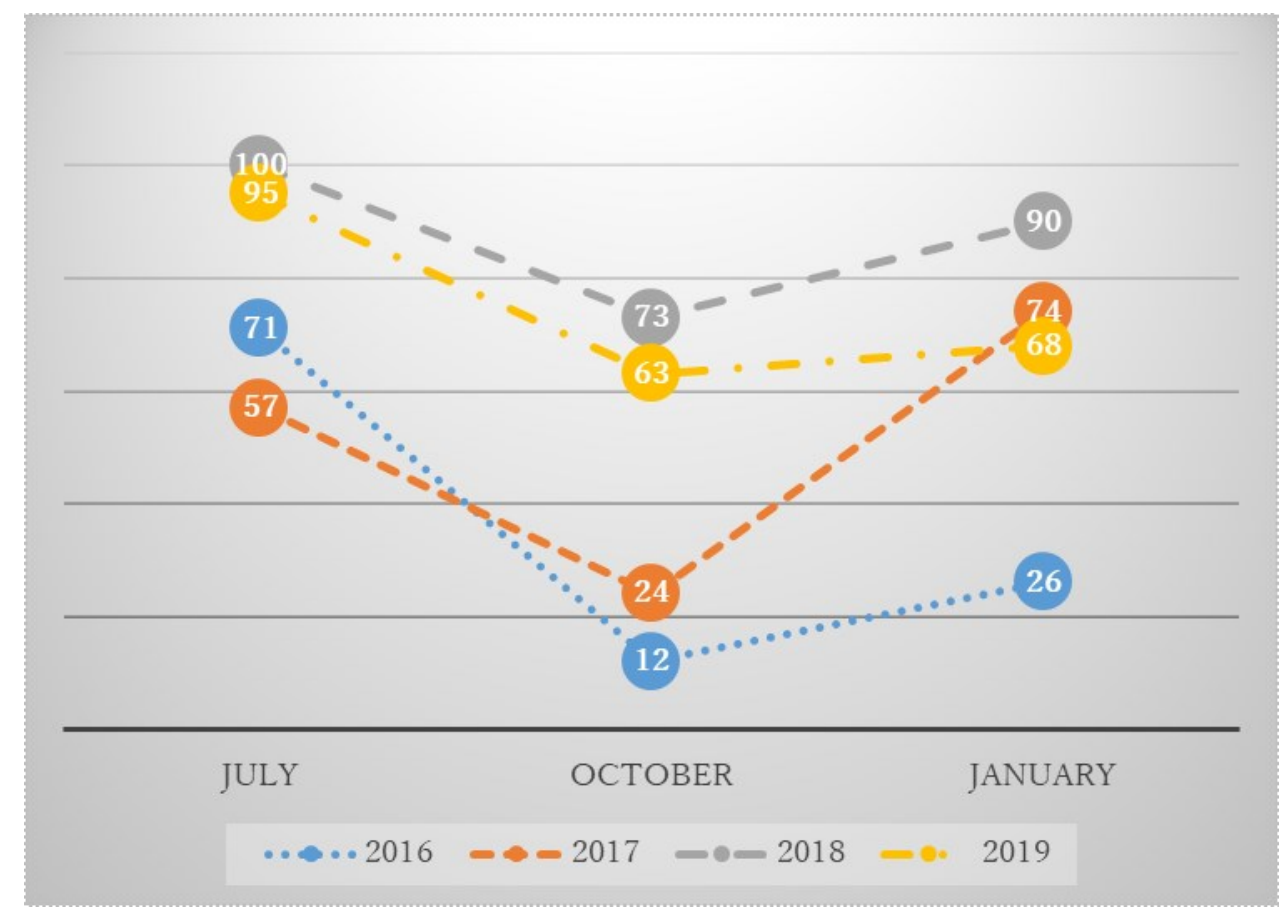

Figure 1. Comparison of Student Motivation between 2016, 2017, 2018, and 2019 - Introductory Group

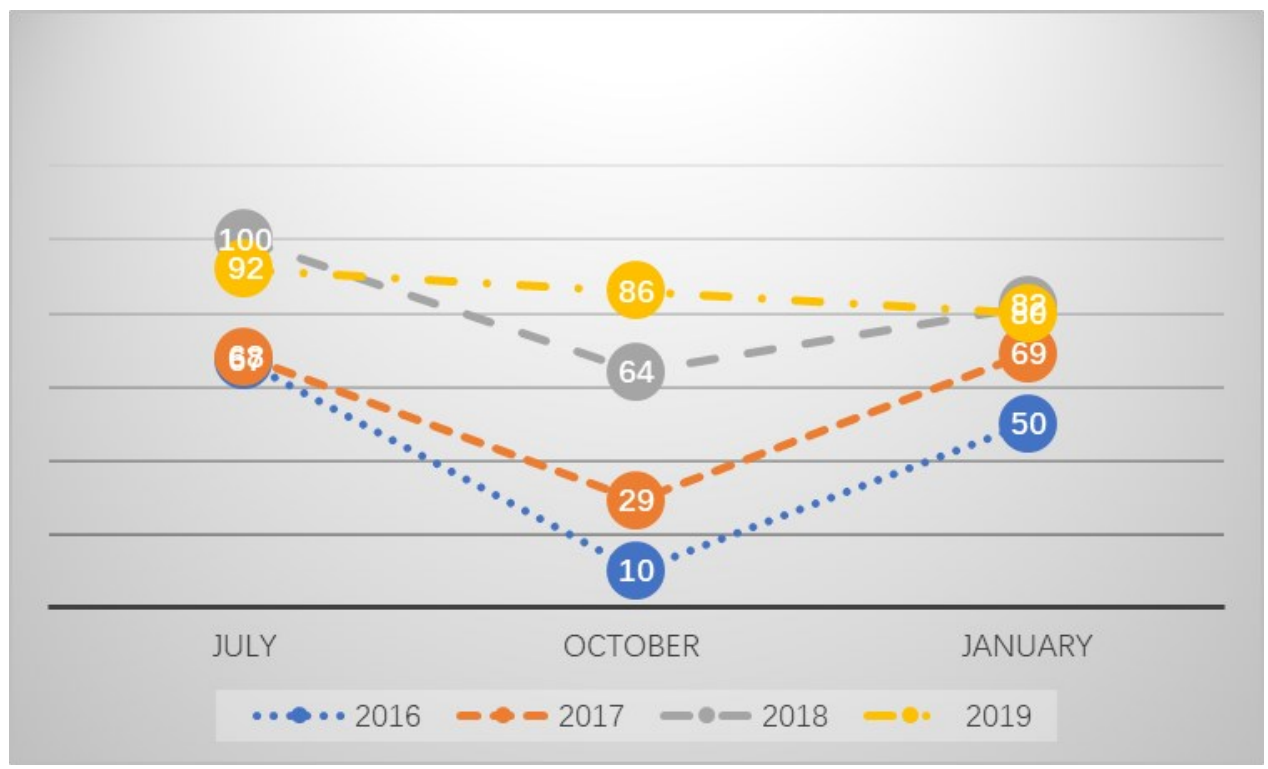

Figure 2. Comparison of Student Motivation between 2016, 2017, 2018, and 2019 - Intermediate I Group 


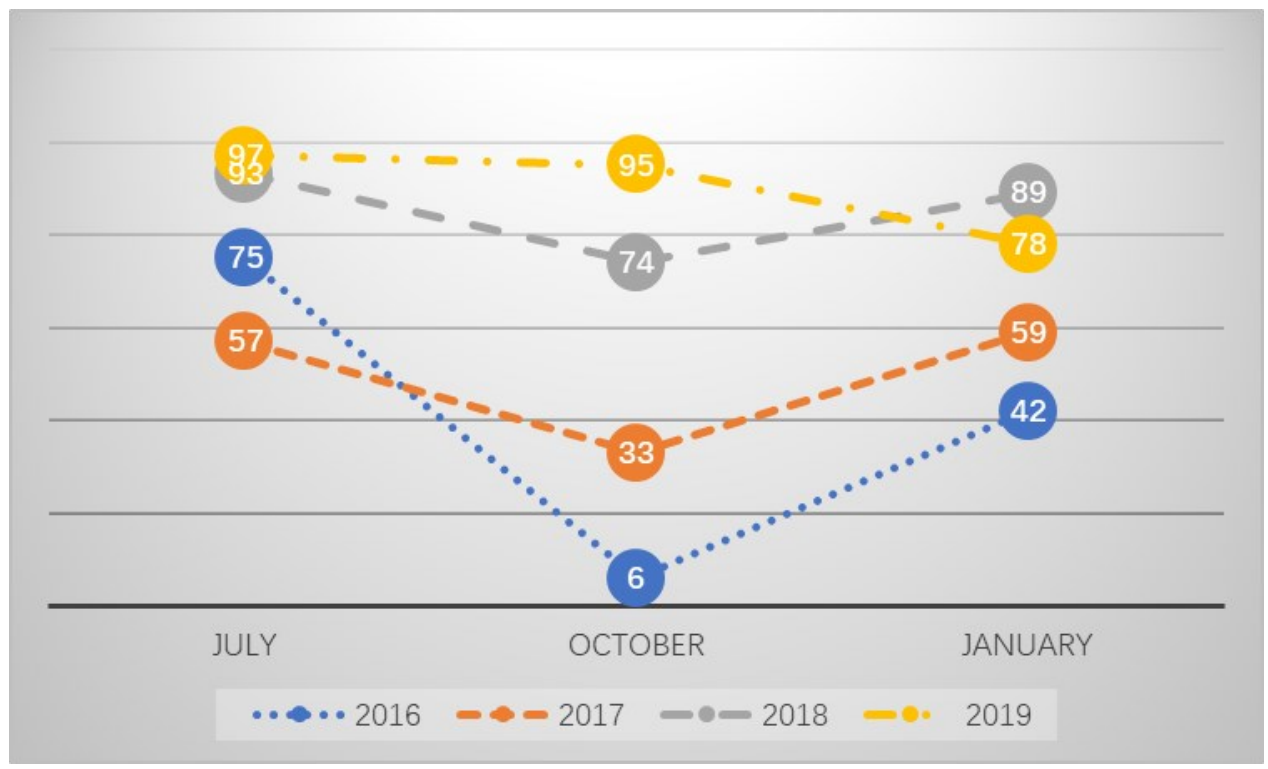

Figure 3. Comparison of Student Motivation between 2016, 2017, 2018, and 2019 - Intermediate II Group

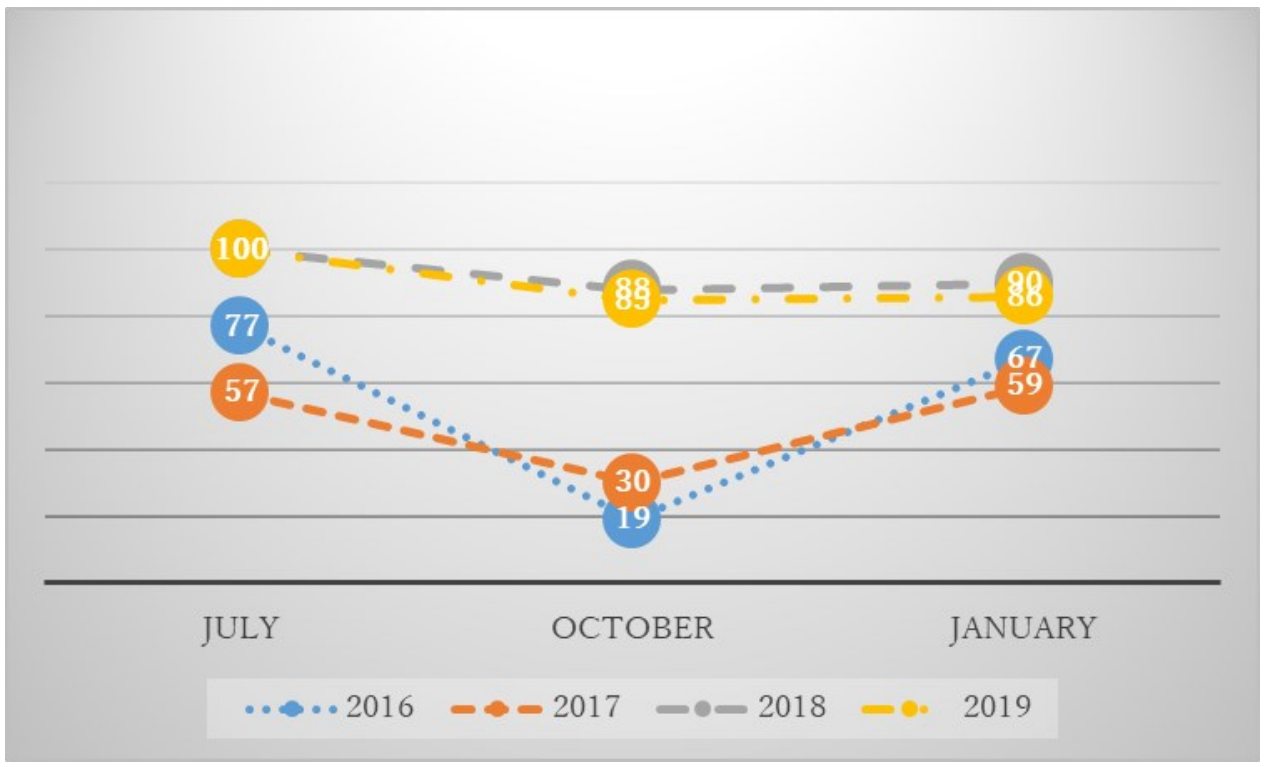

Figure 4. Comparison of Student Motivation between 2016, 2017, 2018, and 2019 - Advanced Group

Todaka (2019) reports that students usually go back to their parents' houses during the summer break, and many of them play with friends from high school. This change of study environment can have negative impacts on students' study habits. This can be seen in the number of students who were able to sustain motivation to enjoy learning English during the spring semester. The data shows that almost all the students were able to sustain their motivation during the spring semester. Nonetheless, the fact that $64 \%$ to $88 \%$ of the students in the 2018 academic-year study and that $63 \%$ to 95\% of the students in the 2019 academic-year study were still able to enjoy their English study during the summer break indicates that those students may have been able to maintain their motivation to enjoy learning English because they were able to self-customize their concrete and enjoyable English study reasons based on the various YouTube videos we provided during the spring semester. Additionally, our information must have truly helped students find enjoyable English study reasons because the data shows that more students, all the proficiency groups, were able to sustain their motivation to improve their English listening skills during the fall semester. 
Next, we examined the participating students' TOEIC scores from April to July during the 2017, 2018 , and 2019 academic years. The following tables indicate the results. The maximum score for the listening test was 495 . The numbers in parentheses indicate standard deviations.

Table 3. TOEIC Scores in April and July 2017 (Spring Semester)

\begin{tabular}{cccc}
\hline Times/Proficiency level & April & July & $\begin{array}{c}\text { P value } \\
\text { F value }\end{array}$ \\
\hline Introductory & $191(51.9)$ & $248(41.3)$ & $\mathrm{P}<.0001 \mathrm{~F}=34.1$ \\
Intermediate I & $224(45.1)$ & $276(46)$ & $\mathrm{P}<.0001 \mathrm{~F}=31.5$ \\
Intermediate II & $239(46.9)$ & $277(45.4)$ & $\mathrm{P}<.0001 \mathrm{~F}=17.2$ \\
Advanced & $277(60.2)$ & $324(52.4)$ & $\mathrm{P}<.0001 \mathrm{~F}=16.7$ \\
\hline
\end{tabular}

Table 4. TOEIC Scores in April and July 2018 (Spring Semester)

\begin{tabular}{cccc}
\hline Times/Proficiency level & April & July & $\begin{array}{c}\text { P value } \\
\text { F value }\end{array}$ \\
\hline Introductory & $222(56.9)$ & $256(43.5)$ & $\mathrm{P}<.039 \mathrm{~F}=4.5$ \\
Intermediate I & $230(39.6)$ & $275(56)$ & $\mathrm{P}<.005 \mathrm{~F}=13.3$ \\
Intermediate II & $255(50)$ & $288(40.2)$ & $\mathrm{P}<.005 \mathrm{~F}=8.4$ \\
Advanced & $294(56)$ & $318(61)$ & $\mathrm{P}<.96 \mathrm{~F}=0.003$ \\
\hline
\end{tabular}

Table 5. TOEIC Scores in April and July 2019 (Spring Semester)

\begin{tabular}{llll}
\hline Times/Proficiency level & April & July & $\begin{array}{l}\text { P value } \\
\text { F value }\end{array}$ \\
\hline Introductory & $188(40.9)$ & $242(39.5)$ & $\mathrm{P}<.0001 \mathrm{~F}=33.1$ \\
Intermediate I & $224(43)$ & $270(41)$ & $\mathrm{P}<.0001 \mathrm{~F}=21.1$ \\
Intermediate II & $245(42)$ & $278(46)$ & $\mathrm{P}<.0032 \mathrm{~F}=9.4$ \\
Advanced & $260(52)$ & $295(51)$ & $\mathrm{P}<.0032 \mathrm{~F}=0.0029$ \\
\hline
\end{tabular}

As seen in the above three tables, students in all proficiency groups (except for the advanced students in the 2018 academic year) made significant improvements in their TOEIC listening scores during the spring semester in each of the three academic year studies. However, the high mean TOEIC scores of the students in all the proficiency groups in April in the 2018 study, when compared with those of students in the 2017 and the 2019 academic year studies might have affected the amount of improvements seen in the spring semester. Because their mean TOEIC scores were relatively high in April to begin with, their scores might have had a ceiling-effect, as the 4-month spring semester was not long enough for them to make statistically significant improvements in TOEIC. Nonetheless, all of the students, in the 2019 academic year study, across all four proficiency groups, significantly improved their TOEIC listening scores, just as the students in the 2017 academic year study improved theirs.

The following tables compare their TOEIC scores in July with those in October (after the summer break) in the 2017 , 2018 the 2019 academic year studies.

Table 6. TOEIC Scores in July and October 2017 (Summer Break in 2017)

\begin{tabular}{cccc}
\hline Times/Proficiency level & July & October & $\begin{array}{c}\text { P value } \\
\text { F value }\end{array}$ \\
\hline Introductory & $247(40.3)$ & $223(46.7)$ & $\mathrm{P}<.008 \mathrm{~F}=7.26$ \\
Intermediate I & $278(45.3)$ & $251(43.3)$ & $\mathrm{P}<.005 \mathrm{~F}=8.31$ \\
Intermediate II & $275(43.6)$ & $258(46.9)$ & $\mathrm{P}<.08 \mathrm{~F}=3.08$ \\
Advanced & $321(53.4)$ & $295(58.7)$ & $\mathrm{P}<.02 \mathrm{~F}=5.24$ \\
\hline
\end{tabular}


Table 7. TOEIC Scores in July and October (Summer Break in 2018)

\begin{tabular}{cccc}
\hline Times/Proficiency level & July & October & $\begin{array}{c}\text { P value } \\
\text { F value }\end{array}$ \\
\hline Introductory & $256(49.5)$ & $246(35)$ & $\mathrm{P}<.42 \mathrm{~F}=0.42$ \\
Intermediate I & $275(56)$ & $260(39.5)$ & $\mathrm{P}<.21 \mathrm{~F}=1.5$ \\
Intermediate II & $288(40.3)$ & $281(39.9)$ & $\mathrm{P}<.49 \mathrm{~F}=.47$ \\
Advanced & $318(61)$ & $318(50)$ & $\mathrm{P}<.96 \mathrm{~F}=.003$ \\
\hline
\end{tabular}

Table 8. TOEIC Scores in July and October 2019 (Summer Break in 2019)

\begin{tabular}{cccc}
\hline Times/Proficiency level & July & October & $\begin{array}{l}\text { P value } \\
\text { F value }\end{array}$ \\
\hline Introductory & $242(39.5)$ & $260(37.7)$ & $\mathrm{P}<.004 \mathrm{~F}=4.2$ \\
Intermediate I & $270(43)$ & $309(73)$ & $\mathrm{P}<.0076 \mathrm{~F}=7.6$ \\
Intermediate II & $278(46)$ & $306(57)$ & $\mathrm{P}<.028 \mathrm{~F}=4.9$ \\
Advanced & $295(51)$ & $340(45)$ & $\mathrm{P}<.00001 \mathrm{~F}=16.8$ \\
\hline
\end{tabular}

As seen above, TOEIC listening scores of students in all proficiency groups significantly worsened over the summer break in the 2017 academic year study. However, the TOEIC listening scores of students in all proficiency groups did not significantly change in the 2018 academic year study. In other words, students in the 2018 study were able to maintain their English listening skills even during the summer break. We are pleasantly surprised however that students in all the proficiency groups in this 2019 academic year study made significant improvements in their TOEIC listening scores during the summer break.

We focused on the concept of the L2 Motivational System with imagery training during the 2017 academic year. Unfortunately, that focus did not help our freshmen sustain their motivation to improve their English listening skills during the summer break. This does not mean though that those techniques will never be able to help our freshmen sustain their motivation to improve their English listening skills, as many other studies have indeed reported the efficacy of those techniques mentioned earlier. It is important to note that most of our de-motivated freshmen feel that they do not have any reason to English study to begin with. Thus, the establishment of concrete and fun English study reasons that are associated with English study had to be carried out so that our freshmen could re-think their ideas on English study. As mentioned earlier, most of our students felt they studied English in high school simply to pass college entrance exams, and thus came to dislike English, as they were, in a sense, forced to study English materials that are only connected to college entrance exams. This interpretation is supported by our questionnaire results in January, 2020 in that some students are still traumatized by the forced English study methods they experienced in high school. Thus, they indicated that they have difficulty viewing English study as a life-enriching activity. In other words, some of the students still have doubts about learning English even with their favorite English songs or movies, from their point of view that studying English is excruciating.

Let us compare the changes in means from April to July, October, and January during the three academic years. 


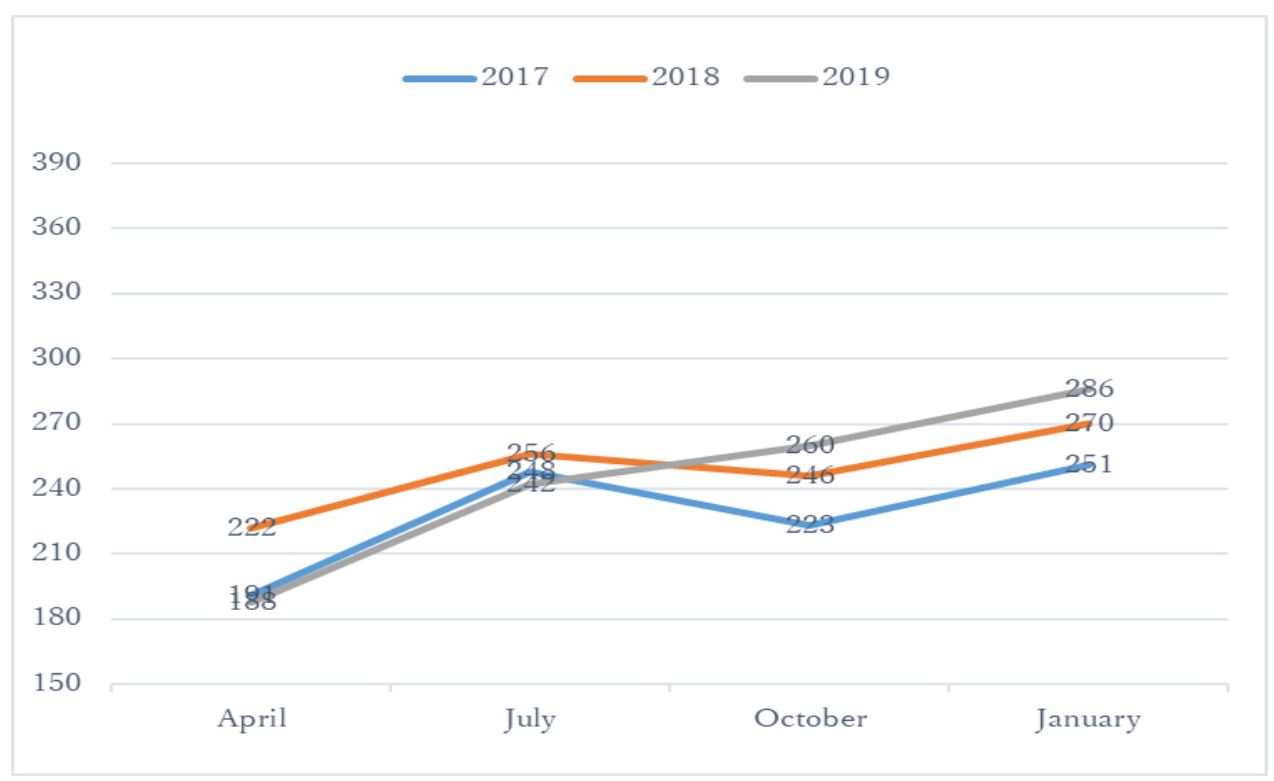

Figure 5. Changes in TOEIC Means during the 2017, the 2018, and the 2019 Academic Years: Introductory Group

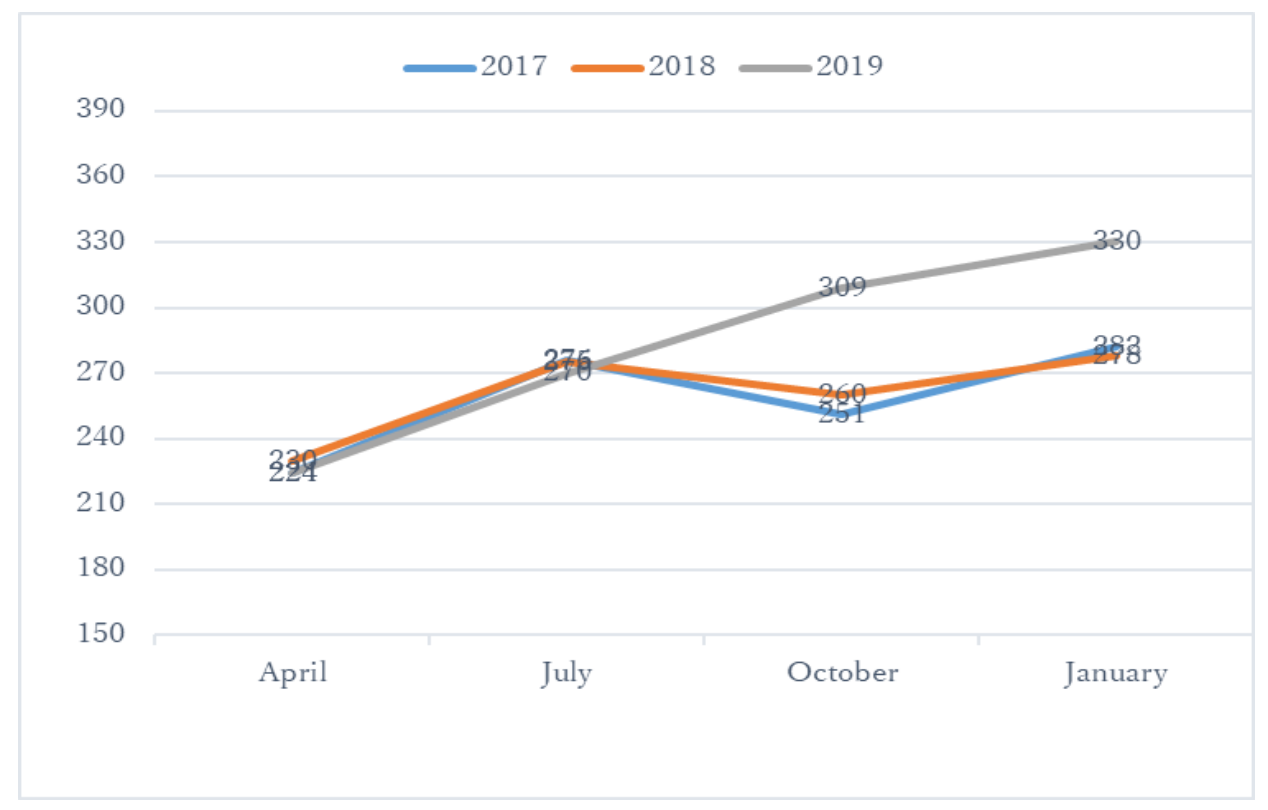

Figure 6. Changes in TOEIC Means during the 2017, the 2018, and the 2019 Academic Years: Intermediate I Group 


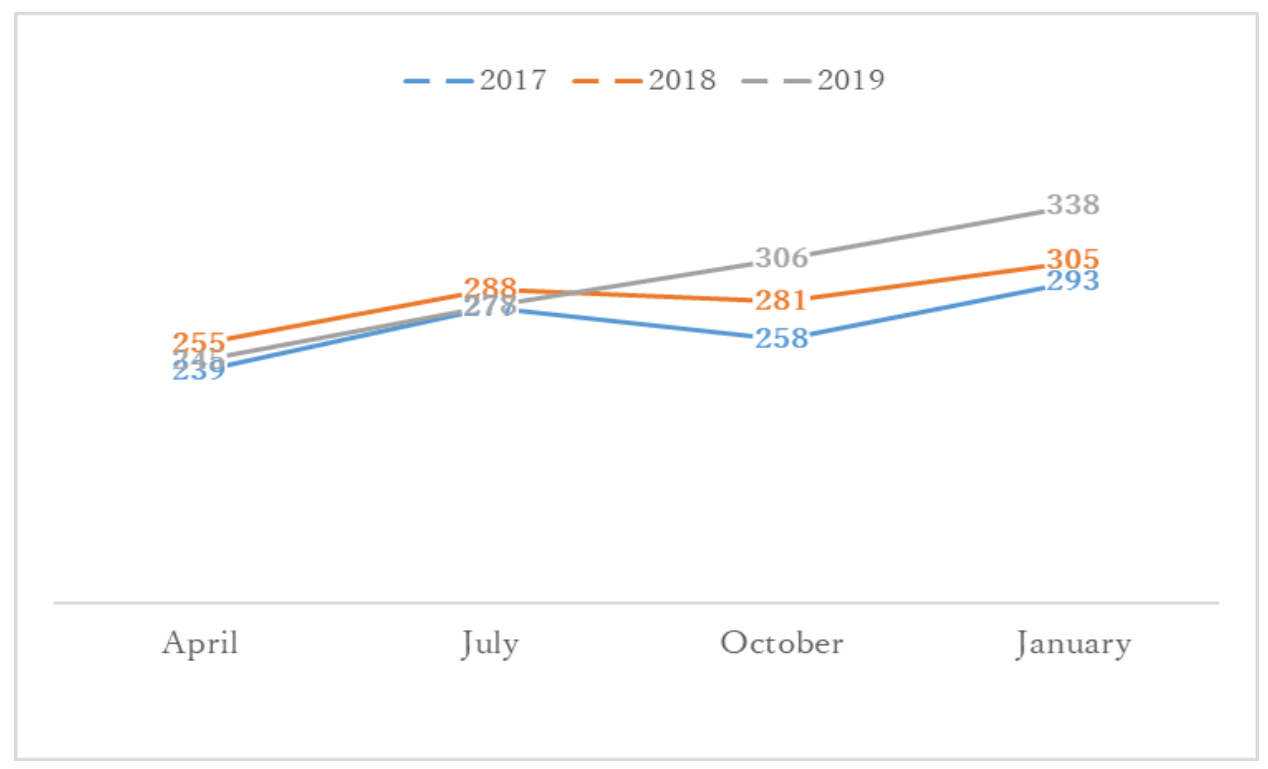

Figure 7. Changes in TOEIC Means during the 2017, the 2018, and the 2019 Academic Years: Intermediate II Group

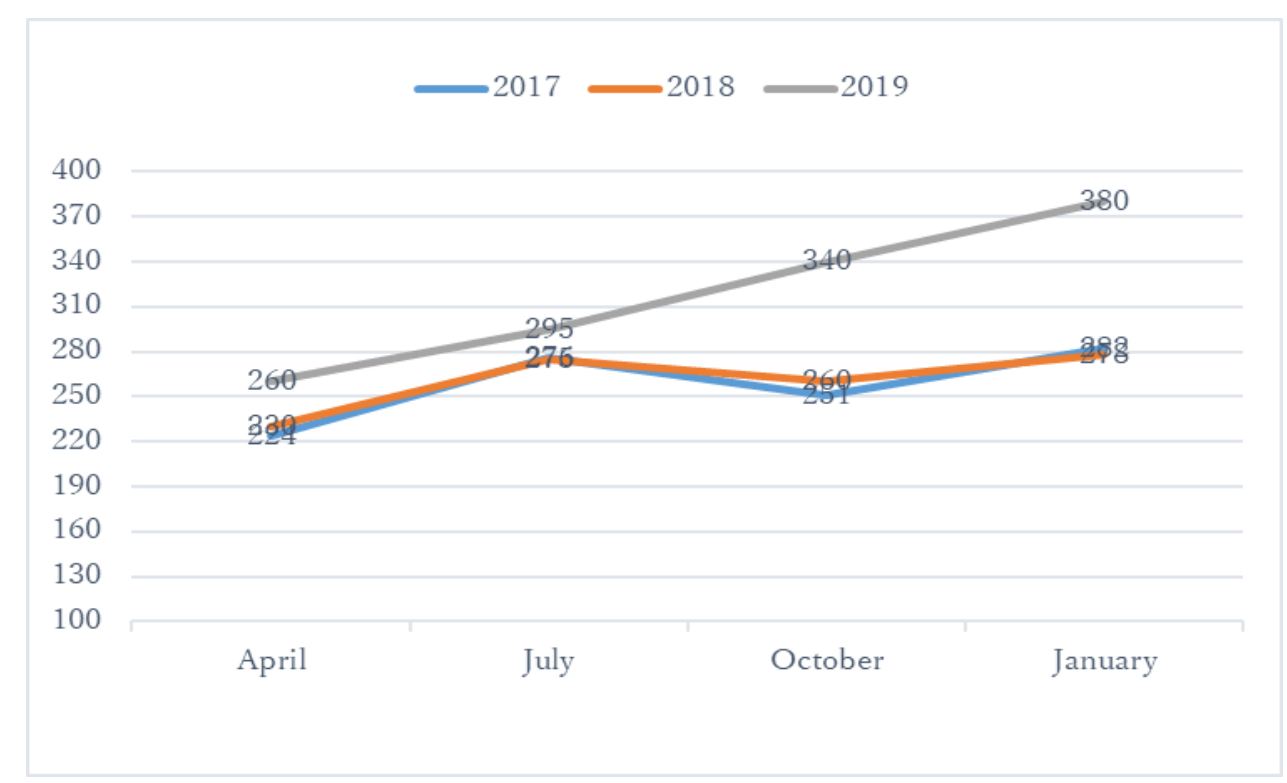

Figure 8. Changes in TOEIC Means during the 2017, the 2018, and the 2019 Academic Years: Advanced Group

Up until the 2018 academic year, students' English listening skills significantly improved during the spring and significantly worsened during the subsequent summer break. Their listening skills then significantly improved again during the fall. This pattern has been consistent with students in all proficiency groups over and over again. That is to say, regardless of student proficiency their scores go up and down alternately through the academic year.

As seen above however, students across proficiency groups demonstrated remarkable and steady progress during the 2019 academic year study. Students in all the proficiency groups made significant improvements in TOEIC during the summer break, and all students, except for those in the intermediate I cohort, also significantly improved their TOEIC listening skills during the fall semester.

Our method of focusing on concrete and fun English study reasons and on helping students enjoy their hobbies and interests using various English YouTube sites really helped our 2018 and 2019 academic year students. In our 2018 academic year, we were able to help our students sustain their motivation to improve their English listening skills 
during the summer break for the first time in our five-year motivation project. , Despite our efforts however, we were not able to help them significantly improve their TOEIC listening scores during the summer and fall semesters in our last project. In this 2019 study however, our students not only significantly improved their TOEIC listening scores during the summer break, but all of them (except for the intermediate I class) also improved their listening scores during the fall semester.

As indicated in table 2, the number of students who were able to sustain motivation to improve their English listening skills did not change drastically from the 2018 academic year to the 2019 academic year. This implies that we are on the right track to help de-motivated college freshmen re-gain their motivation to study English by focusing on the things they like to do, i.e., their hobbies and other personal interests. Some of our advanced students have indicated that they now understand the importance of English skills in their future lives. Indeed, most of our freshmen have come to realize that they can truly improve their English listening skills without considering English as a school subject. Some are ready to make use of the concept of future EFL selves and/or the four sources of self-efficacy theory to further improve their other English skills. However, we would like to continue to help our de-motivated freshmen understand that English learning can be fun, and that it can be used as with life-long enjoyment to enrich their future lives.

\section{Conclusion}

We have been conducting studies of learning motivation of de-motivated Japanese college EFL learners over the last five years. We focused our attention on students' perceived self-efficacy of EFL learning during the first two years and on the concept of the 12 Motivational System with imagery training in the third year. Self-efficacy theory is described as "people's beliefs in their capabilities to produce desired effects by their own actions" (Bandura, 1997, p. vii). It is considered to be the most important factor in determining how people choose to engage and how much effort they will make when faced with challenges (Maddux, 2002). Thus, self-efficacy is not perceived as a skill, a predicate to behavior, or intention to attain a particular goal. Rather, it is more about "what I believe I can do with my skills under certain conditions" (Maddux, 2002). Since Bandura (1977) proposed self-efficacy theory, many articles have been published applying the theory in various fields such as psychology, sociology, kinesiology, and medicine.

During the first two years, we were able to boost students' perceived self-efficacy beliefs about their English listening skills during the spring semester; however, in those two academic years, students could not sustain their motivation during the subsequent summer breaks. Thus, we decided to incorporate intervention activities with an emphasis on imagery in our 2017 study. In the 2017 study, our activities were found to help our freshmen study participants sustain their motivation to study English during the two-month summer break at a rate almost three times that of the previous year. That improvement however still only yielded a total of $30 \%$ of students who were able to sustain motivation during the summer break. In addition, those students' TOEIC scores still did not significantly improve during the fall semester.

In the 2018 academic year study, we utilized modified blended learning techniques. But rather than simply utilize mobile phones in class, we provided students with various YouTube sites on which relevant information on their hobbies and interests can be found with mobile phones as learning support outside of class. Of course, students, who prefer using conventional devices such as CD and DVD players, can still enjoy improving English listening skills by listening to English songs and/or watching favorite movies on those devices.

Based on our findings, we were able to help students sustain motivation even during the summer break in this study. This means that our modified blended learning techniques focusing on the establishment of concrete and fun English study reasons can really help most de-motivated Japanese college freshmen sustain motivation to improve their English listening skills, even during the summer break. It is important to note however that the 2018 academic year method did not help our freshmen significantly improve their TOEIC listening scores during the summer break and the fall semester. In this present 2019 study, we decided to explicitly teach students, in class, how to access various sites on YouTube, and showed some example sites that other freshmen were interested in. This minor change from the 2018 pedagogical method not only continued to help our freshmen significantly improve their listening skills during the summer break, but also to help many of them (all but the intermediate I class) significantly improve their listening skills during the fall semester.

Through our research, some students have come to realize that they can improve their English listening skills while listening to their favorite songs, and watching movies, sports events, and international games. Thus, their self-efficacy beliefs about their English skills must have been enhanced, to the point that some advanced students have begun to think about their future ESL selves to make use of their English skills for future careers. Kelson (2009) reported on the 
importance of using supplementary tools such as sites on YouTube to improve English skills. We truly found its significance in this study as the only change we made in our method from the 2018 academic year study was to help freshmen understand how to access sites on YouTube show some sites in class to help them appreciate how to make use of those sites to improve their English listening skills.

Although we haven't found a way to convince all de-motivated Japanese college freshmen that English study can be fun, and that English learning can be a part of their pastime activities, we are on the right track to assist our college freshmen in changing their view of English study and re-motivating them to enjoy learning English. Subsequent studies will be therefore conducted to search for better ways to help students realize that their English study can enhance their future lives.

\section{References}

Agawa, T., Abe, E., Ishizuka, M., Okuda, S., Carreria-Matsuzaki, J., Sano, F., \& Shimizu, S. (2011). Preliminary study of demotivating factors in Japanese university English learning. The Language Teacher, 35(1), 11-16. https://doi.org/10.37546/JALTTLT35.1-2

Anaydubalu, C. C. (2010). Self-efficacy, anxiety, and performance in the English language among middle-school students in English language program in Satri Suriyothai School, Bangkok. International Journal of Human and Social Sciences, 5(3), 193-198.

Balbay, S., \& Kilis, S. (2017). Students' perception of the use of a YouTube channel specifically designed for an academic presentation skills course. Eurasian Journal of Applied Linguistics, 3(2), 235-251. https://doi.org/10.32601/ejal.461003

Balbay, S., \& Selcan, K. (2017). Students' perceptions of the use of a YouTube channel specifically designed for an academic speaking skills course. Eurasian Journal of Applied Linguistics, 3(2), 235-251. https://doi.org/10.32601/ejal.461003

Banditvilai, C. (2016). Enhancing students' language skills through blended learning. The Electronic Journal of e-Learning, 14(3), 223-232.

Bandura, A. (1977). Self-efficacy: Toward a unifying theory of behavioral changes. Psychological Review 84, 191-215. https://doi.org/10.1037/0033-295X.84.2.191

Benmouhoub, L. (2015) YouTube videos as pedagogical tools to improve EFL learners' oral fluency. Retrieved from https://pdfs.semanticscholar.org/c5ea/03e71 ca542db6b62efd18add81574a155a42.pdf

Boo, Z., Dornyei, Z., \& Ryan, S. (2015). L2 motivation research 2005-2014: Understanding a publication surge and a changing landscape. System, 55, 147-157. https://doi.org/10.1016/j.system.2015.10.006

Chan, H. Y. L. (2014). Possible selves, vision, and dynamic systems theory in second language learning and teaching $(\mathrm{PhD}$ thesis). University of Nottingham. Retrieved from http://eprints.nottingham.ac.uk/14301/1/Letty_Thesis_June2014.pdf

Chen, C. M., \& Li, Y. L. (2010). Personalized mobile English vocabulary learning system based on item response theory and learning memory cycle. Computers \& Education, 51(2), 624-645. https://doi.org/10.1016/j.compedu.2007.06.011

Cheung, C. K. (2001). The use of popular culture as a stimulus to motivate secondary students' English learning in Hong Kong. ELT Journal, 55(1), 55-61. https://doi.org/10.1093/elt/55.1.55

Cho, K., Lee, S., Joo, M-H., \& Becker, B. J. (2018). The effects of using mobile devices on student achievement in language learning: A meta-analysis. Education Sciences, 8(3), 105. https://doi.org/10.3390/educsci8030105

Cubukcu, F. (2008). A study on the correlation between self-efficacy and foreign language learning anxiety. Journal of Theory and Practice in Education, 4(1), 148-158.

Deci, E. L., \& Ryan, R. M. (2000). The "what" and "why" of goal pursuits: Human needs and self-determination of behavior. Psychological Inquiry, 11(4), 227-268. https://doi.org/10.1207/S15327965PLI1104_01

Dennissen, J. J. A., Zarrett, N. R., \& Eccles, J. S. (2007). I like to do it, I'm able, and I know I am: Longitudinal couplings between domain specific achievement, self-concept, and interest. Child Development, 78(2), 430-447. https://doi.org/10.1111/j.1467-8624.2007.01007.x

Dörnyei, Z. (2001). Teaching and researching motivation. Harlow, England: Longman. 
Dörnyei, Z. (2005). Introduction. In Z. Dörnyei (Ed.), Attitudes, orientations, and motivations in language learning: Advances in theory, research and applications. Blackwell Publishing.

Dörnyei, Z. (2005). The psychology of the language learner: Individual differences in second language acquisition. Mahwah, NJ: Lawrence Erlbaum Associates. https://doi.org/10.1177/0261927X05281424

Dörnyei, Z. (2009). The L2 motivational self system. In Z. Dornyei \& E. Ushioda (Eds.), Motivation, language identity and the L2 self (pp. 9-42). Bristol, UK: Multilingual Matters. https://doi.org/10.21832/9781847691293-003

Dörnyei, Z., \& Chan, L. (2013). Motivation and vision: An analysis of future L2 self images, sensory styles, and imagery capacity across two target languages. Language Learning, 63(3), 437-362. https://doi.org/10.1111/lang.12005

Dörnyei, Z., \& Schmidt, R. (Eds.) (2001). Motivation and second language acquisition. Honolulu, HI: University of Hawaii. https://doi.org/10.1017/S0272263101241059

Duffy, P. (2008). Engaging the YouTube google-eyed generation: Strategies for using web 2.0 in teaching and learning. Electronic Journal of e-Learning, 6(2), 119-130.

Erkan, Y. D., \& Saban, A. I. (2011). Writing performance relative to writing apprehension, self-efficacy in, writing and attitudes towards writing: A correlational study in Turkish tertiary-level EFL. The Asian EFL Journal Quarterly, 13(1), 163-191.

Graham, S. (2006). A study of students' metacognitive beliefs about foreign language study and their impact on learning. Foreign Language Annals, 39(2), 296-309. https://doi.org/10.1111/j.19449720.2006.tb02267.x

Hsieh, P. H. P., \& Schallert, D. L. (2008). Implications from self-efficacy and attribution theories for an understanding of undergraduates motivation in a foreign language course. Contemporary Educational Psychology, 33, 513-532. https://doi.org/10.1016/j.cedpsych.2008.01.003

Hsieh, P. P., \& Kang, H. S. (2010). Attribution and self-efficacy and their interrelationship in the Korean EFL context. Language Learning, 60(3), 606-627. https://doi.org/10.1111/j.1467-9922.2010.00570.x

Hsu, C. K., Hwang, G. J., \& Chang, C. K. (2013). A personalized recommendation-based mobile learning approach to improving the reading performance of EFL students. Computers and Education, 63, 327-336. https://doi.org/10.1016/j.compedu.2012.12.004

Huang, Y., M. Huang, S, H., \& Lin, Y. T. (2012). A ubiquitous English vocabulary learning system: Evidence of active/passive attitudes vs. usefulness/ease-of-use. Computers and Education, 58, 273-282. https://doi.org/10.1016/j.compedu.2011.08.008

Hwang, W. Y., Huang, Y. M., Shadiev, R., \& Chen, S. Y. (2014). Effects of using mobile devices on English listening diversity and speaking for EFL elementary students. Australasian Journal of Educational Technology, 30(5), 503-516. https://doi.org/10.14742/ajet.237

Ivic, V., \& Jakopec, T. (2016). Using mobile application in foreign language learning: a case study. Libellarium, 9(2), 217-230. https://doi.org/10.15291/libellarium.v9i2.288

Jahedizadeh, S., Ghanizadeh, A., \& Ghonsooly, B. (2016). The role of EFL learners' demotivation, perceptions of classroom activities, and mastery goal in predicting their language achievement and burnout. Asian-Pacific Journal of Second and Foreign Language Education, 1, 1-16. https://doi.org/10.1186/s40862-016-0021-8

Keblawi, F. (2020). A review of language learning motivation theories. Retrieved from https://www.researchgate.net/publication/265623577_A_review_of_language_learning_motivation_theories

Kelsen, B. (2009). Teaching EFL to the iGeneration: A Survey of Using YouTube as Supplementary Material with College EFL Students in Taiwan. CALL-EJ, 10.

Kim, D., \& Kim, D. (2012). Effect of screen size on multimedia vocabulary learning. British Journal of Educational Technology, 43(1), 62-70. https://doi.org/10.1111/j.1467-8535.2010.01145.x

Lamb, M. (2017). The motivational dimension of language teaching. Language Teaching, 50(3), 301-346. https://doi.org/10.1017/S0261444817000088

Larson, L. J. (2010). Teacher and student perspectives on a blended learning intensive English program writing course (Graduate Thesis and Dissertation). Ames: Iowa State University.

Maddux, J. E. (2002). Self-efficacy: The power of believing you can. In: Snyder, C. R. and S. J. Lopez (Eds.), 
Handbook of positive psychology. N.Y.: Oxford University Press.

Magid, M. (2011). A validation and application of the L2 motivational self-system among Chinese learners of English (Unpublished $\mathrm{PhD}$ Thesis). University of Nottingham.

Magogwe, J. M., \& Oliver, R. (2007). The relationship between language learning strategies, proficiency, age and self-efficacy beliefs: A study of language learners in Botswana. SYSTEM, 35, 338-352. https://doi.org/10.1016/j.system.2007.01.003

Mahyuddin, R., Elias, H., Cheong, L., Muhamad, M., Noordin, N., \& Abdullah, M. (2006). The relationship between students' self-efficacy and their achievement. Journal Pendidikadan Pendidikan, Jil, 21, 61-71.

Mahyuddin, R., Elias, H., Markus, H., \& Nurius, P. (1987). Possible selves. American Psychologist, 41, 954-969. https://doi.org/10.1037/0003-066X.41.9.954

Martinovic, A. (2018). The L2 motivational self system: Differences among learners. Jwzikoslovlje, 19(1), 133-157.

Mills, N., Pajares, F., \& Herron, C. (2006). A reevaluation of the role of anxiety: Self-efficacy, anxiety, and their relation to reading and listening proficiency. Foreign Language Annals, 39(2), 276-294. https://doi.org/10.1111/j.1944-9720.2006.tb02266.x

Mills, N., Pajares, F., \& Herron, C. (2007). Self-efficacy of college intermediate French students: Relation to Achievement and motivation. Language Learning, 57(3), 417-442. https://doi.org/10.1111/j.1467-9922.2007.00421.x

Morris, T., Spittle, M., \& Watt, A. P. (2005). Imagery in sport. Champaign, IL: Human Kinetics.

Multon, K. D., Brown, S. D., \& Lent, R. W. (1991). Realtion of self-efficacy beliefs to academic outcomes: Meta-analytic investigation. Journal of Counseling Psychology, 38, 30-38. https://doi.org/10.1037/0022-0167.38.1.30

Munezane, Y. (2013). Motivation, ideal L2 self and valuing of global English. In M. T. Apple, D. D. Silva, \& T. Feller (Eds.), Language learning motivation in Japan, (pp. 152-168). Bristol: Multilingual Matters. https://doi.org/10.21832/9781783090518-011

Noels, K. A. (2001). Learning Spanish as a second language: Learners' orientations and perceptions of their teachers' communication style. Language Learning, 51(1), 107-144. https://doi.org/10.1111/0023-8333.00149

Noels, K. A., Pelletier, L. G., Clement, R., \& Vallerand, R. J. (2000). Why are you learning a second language? Motivational orientations and self-determination theory. Language Learning, 50(1), 57-85. https://doi.org/10.1111/0023-8333.00111

Ottingen, G. (1995). Cross-cultural perspectives on self-efficacy. In A. Bandaranaike (Ed.), Self-efficacy in changing societiespp. New York, NY, Cambridge University Press. https://doi.org/10.1017/CBO9780511527692.007

Ozer, O., \& Kilic, F. (2018). The effect of mobile-assisted language learning environment on EFL students' academic achievement, cognitive load and acceptance of mobile learning tools. EURASIA Journal of Mathmatics, Science, and Technology Education, 14(7), 2915-2928. https://doi.org/10.29333/ejmste/90992

Pajares, F. (1996). Self-efficacy beliefs in academic settings. Reviews of Educational Research, 66(4), 543-578. https://doi.org/10.3102/00346543066004543

Prihastiwi, L., Rochsantiningsih, D., \& Suparno. (2017). Blended learning to activate English as a foreign language (EFL) learners' autonomy. Journal of Social Sciences and Humanities, 25(8), 1-10.

Raoofi, S., Tan, B. H., \& Chan, S. H. (2012). Self-efficacy in second language learning contexts. English Language Learning, 5(11), 60-73. https://doi.org/10.5539/elt.v5n11p60

Roodt, S., \& De Villiers, C. (2011). Using YouTube as an innovative tool for collaborative learning at undergraduate level in tertiary education. Proceedings of the AIS SIB-ED IAIM 2011 Conference.

Roodt, S., \& Peier, D. (2013). Using YouTube in the classroom for the net generation of students. Issues in informing Science and Information Technology, 10, 473-487. https://doi.org/10.28945/1823

Ryan, S., \& Mercer, S. (2013). Why the imagination? [Special Issue] Studies in Second Language learning and Teaching, 3(3), 337-341. https://doi.org/10.14746/ssllt.2013.3.3.1

Sampson, R. (2012). The language-learning self, self-enhancement activities, and self-perceptual change. Language Teaching Research, 16(3), 317-335. https://doi.org/10.1177/1362168812436898 
Sampson, R. (2016). Complexity in Classroom Foreign Language Learning Motivation: A practitioner Perspective from Japan. Multilingual Matters. https://doi.org/10.21832/9781783095896

Snelson, C. (2009). Web-based video for e-learning: Tapping into the YouTube phenomenon. In H. Yang \& S. Yuen (Eds.), Collective intelligence and e-learning 2.0: Implications of web-based communities and networking (pp. 147-166). PA: IGI. https://doi.org/10.4018/978-1-60566-729-4.ch009

Teeter, L. J. (2017). Improving motivation to learn English in Japan with a self-study shadowing application. Languages, 2, 19. https://doi.org/10.3390/languages 2040019

Tilfarlioglu, F. T., \& Ciftci, F. S. (2011). Supporting self-efficacy and learner autonomy in relation to academic success in EFL classrooms. (A Case Study). Theory and Practice in Language Studies, 1(10), 1284-1294. https://doi.org/10.4304/tpls.1.10.1284-1294

Todaka, Y. (1995). A preliminary study of voice quality differences between Japanese and American English: Some pedagogical suggestions. JALT Journal, 17(2), 261-268.

Todaka, Y. (2009). Dainigengoshuutoku no mtome: kokusaihen (Review of second language studies of English communication skills: International studies). Journal of English Phonetic Society of Japan, 379-394.

Todaka, Y. (2013). Self-efficacy theory and beyond. Journal of Educational and Social research, 3(7), 359-365.

Todaka, Y. (2017a). Self-efficacy of English listening skills in Japanese college EFL learners. European Journal of English Language Teaching, 2(1), 93-120.

Todaka, Y. (2017b). How to motivate de-motivated Japanese college EFL learners. European Journal of English Language Teaching, 2(4), 87-113.

Todaka, Y. (2018). Concrete English study reasons: A crucial prerequisite for de-motivated Japanese college EFL learners, Proceedings of International Academic Conference on Global Education. Teaching and Learning, 10-28 (on CD), 2018 (Aug. 17th-18th) Budapest, Hungary.

Todaka, Y., \& Misono, K. (2009). Dainigengoshuutoku no matome: kokunaihenn ((Review of second language studies of English communication skills: Studies in Japan). Journal of English Phonetic Society of Japan, 395-406.

Todaka. (2019). Modified Blended Learning: De-motivated Japanese College EFL Learners Sustain Motivation to Improve English Listening Skill. International Journal of Innovation and Research in Educational Sciences, 6(2), 263-284.

Ushioda, E. (2009). A person-in-context relational view of emergent motivation, self and identity. In Z. Dorynei \& E. Ushioda (Eds.), Motivation, Language Identity and the L2 Self (pp. 215-228). Bristol: Multilingual Matters. https://doi.org/10.21832/9781847691293-012

Vance, T. (1987). An introduction to Japanese phonology. Albany: State University of New York Press.

Viberg, O., \& Grönlund, Å. (2012). Mobile Assisted Language Learning: A Literature Review. CEUR Workshop Proceedings, 955.

Vohs. K., Baumeister, B., Jean, M., Twenge, J., Nelson, N., \& Tice, D. (2008). Making choices impairs subsequent self-control: A limited-resource account of decision making, self-regulation, and active initiative. Journal of Personality and Social Psychology, 94(5), 883-898. https://doi.org/10.1037/0022-3514.94.5.883

Watkins \& Watikins. (2011). Using YouTube in the EFL classroom. Language Education in Asia, 2(1), 113-119. https://doi.org/10.5746/LEiA/11/V2/I1/A09/Watkins_Wilkins

Watkins \& Watikins. (2011). Using YouTube in the EFL classroom. Language Education in Asia, 2(1), 113-119.

Yashima, T. (2002). Willingness to communicate in a second language: The Japanese EFL context. The Modern Language Journal, 86, 54-66. https://doi.org/10.1111/1540-4781.00136

Yashima, T. (2009). International posture and the ideal L2 self in the Japanese EFL context. In Z. Dornyei and E. Ushioda (Eds.), Motivation, Language identity and the L2 Self (pp. 144-163). Bristol: Multilingual Matters. https://doi.org/10.21832/9781847691293-008

Zaidi, A., Awaludin, F. A., Karim, R. A., Ghani, F. C., Rani, M. S. A., \& Ibrahim, N. (2018). University students' perceptions of YouTube usage in (ESL) classrooms. International Journal of Academic Research in Business and Social Sciences, 8(1), 541-553. https://doi.org/10.6007/JJARBSS/v8-i1/3826 


\section{Note}

Note 1. Although 200 freshmen entered our university in April, the course in Language Acquisition in the fall shifted from a required course to an elective, therefore, data on 148 freshmen students were analyzed in the present study.

Appendix 1. A Questionnaire on EFL Study Reasons in Secondary and in College

1. Do you understand why you need to study English in college?

2. If so, select your reasons from below.

(1) I know what I want to be in the future.

(2) I like English songs so that I want to be able to understand them.

(3) I like English movies so that I want to be able to understand them.

(4) I have foreign friends so that I want to improve my English speaking skills.

(5) I want make friends with people from different parts of the world.

(6) I want to study abroad in the future.

(7) Other reasons.

3. For those students who don't understand the reasons why you need to study English in college, why did you study English in secondary school?

(1) I had to study English because English was a compulsory subject.

(2) My parents or teachers told me to do so.

(3) I studies English for college entrance exams.

(4) Other reasons.

4. Have you decided what you want to be in the future, yet?

5. If so, what do you want to be in the future?

Appendix 2. English study motivation questionnaire items

Q1. Have you been able to sustain your motivation to study English (in the spring semester, the summer, the fall) since you entered university?

Q2. If so, let us understand why you were able to do so. If not, let us understand why you weren't able to do so.

Q3. For those students who were able to sustain motivation to study English, do you always make concrete plans to accomplish study objectives?

Q4. For those students who were able to sustain their motivation to study English and always make concrete plans to accomplish study objectives, do you reflect on your study strategies to see if your learning strategies are working or not?

Q5. For those students who have completely lost interest in English study, what caused you to lose interest in English study?

\section{Copyrights}

Copyright for this article is retained by the author(s), with first publication rights granted to the journal.

This is an open-access article distributed under the terms and conditions of the Creative Commons Attribution license (http://creativecommons.org/licenses/by/4.0/). 